\title{
Pengaruh intervensi pendidikan gizi terhadap peningkatan pengetahuan gizi, perubahan asupan zat gizi dan indeks massa tubuh remaja kelebihan berat badan
}

\author{
Nurmasyita $^{1}$, Bagoes Widjanarko² ${ }^{2}$ Ani Margawati ${ }^{3}$
}

\begin{abstract}
Background: Adolescence overweight due to excessive intake and physical inactivity. This situation will continue until adulthood and cause degenerative diseases. The prevalence of overweight adolescents in senior high school Pontianak is 16,8\% (higher than prevalence of obese adolescents in Indonesia).

Objective: Analyze impact of nutrition education intervention to increase nutritional knowledge, change nutrient intake and Body Mass Index (BMI) among adolescent overweight in Pontianak high school.

Methods: Quasi-experimental study design with control group pre-post test design. Nutrition education intervention to treatment group was gave once a week for 3 months and control group was gave only one for 3 months study. The subject are 73 overweight high school students, taken by purposive sampling and divided into 2 groups: 36 treatment group and 37 control group. Statistical analysis using paired t-test, Wilcoxon test, Independent t-test, Mann-Whitney Test and covariance.

Results: This result shows that nutrition education intervention increase nutrition knowledge score (9.58 \pm 11.82$)$ and fiber intake $(1.05 \pm 5.29 \mathrm{~g})$ in treatment group; reduce energy sufficiency rate in treatment and control group $(12.42 \pm 16.77 \%$ and $10.18 \pm 0.54 \%)$; reduce protein adequacy rate $(7.61 \pm 12.05 \% \%)$, carbohydrate intake $(3.78 \pm 6.71 \%)$ and reduce fat intake $(3.11 \pm 3.96 \%)$ in treatment group; reduce BMI in treatment and control group $\left(0.58 \pm 0.67 \mathrm{~kg} / \mathrm{m}^{2}\right.$ and $\left.0.12 \pm 0.34 \mathrm{~kg} / \mathrm{m}^{2}\right)$.

Conclusion: Nutrition education in overweight adolescent can decrease BMI among them through increase their nutrition knowledge. Nutrition knowledge of overweight adolescent decrease energy adequacy level, protein adequacy level, carbohydrate intake percentage, fat intake percentage, and increase fiber intake.
\end{abstract}

Keywords: Adolescents, overweight, nutrition education, nutrient intake, BMI

\section{ABSTRAK}

Latar Belakang: Kelebihan berat badan masa remaja disebabkan oleh asupan yang berlebihan dan aktivitas fisik yang kurang. Keadaan ini akan berlanjut sampai masa dewasa dan akan menyebabkan penyakit degeneratip. Prevalensi remaja kelebihan berat badan di SMA kota Pontianak mencapai 16,8\% (lebih tinggi dari prevalensi remaja gemuk di Indonesia).

Tujuan penelitian: Menganalisis pengaruh intervensi pendidikan gizi terhadap peningkatan pengetahuan gizi, perubahan asupan zat gizi dan Inseks Massa Tubuh (IMT) remaja kelebihan berat badan.

Metode: Desain penelitian quasi eksperimen with control group pre pos-test design. Intervensi pendidikan gizi pada kelompok perlakuan diberikan seminggu sekali selama 3 bulan dan kelompok kontrol hanya sekali selama 3 bulan penelitian. Jumlah subjek 73 siswa SMA dengan kelebihan berat badan yang diambil secara purposive sampling dan dibagi 2 kelompok yaitu 36 kelompok perlakuan dan 37 kelompok kontrol. Analisis statistik menggunakan Paired t-test, wilcoxon test, Independent t-test, Mann-Whitney Test dan uji Multivariat kovarian.

Hasil: Setelah intervensi pendidikan gizi terdapat peningkatan skor pengetahuan gizi $(9,58 \pm 11,82)$ dan asupan serat $(1,05 \pm 5,29$ gr) pada kelompok perlakuan; penurunan Tingkat Kecukupan Energi pada kelompok perlakuan dan kontrol (12,42 $\pm 16,77 \%$ dan

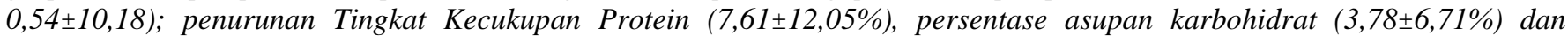
persentase asupan lemak $(3,11 \pm 3,96 \%)$ pada kelompok perlakuan; penurunan IMT pada kelompok perlakuan dan kontrol $\left(0,58 \pm 0,67 \mathrm{~kg} / \mathrm{m}^{2}\right.$ dan $\left.0,12 \pm 0,34 \mathrm{~kg} / \mathrm{m}^{2}\right)$.

Simpulan: Pendidikan gizi pada remaja kelebihan berat badan menurunkan IMT remaja melalui peningkatan pengetahuan tentang gizi. Pengetahuan gizi remaja kelebihan berat badan dapat menurunkan Tingkat Kecukupan Energi, Tingkat Kecukupan Protein, persentase asupan karbohidrat, persentase asupan lemak dan meningkatkan asupan serat.

Kata Kunci: Remaja, kelebihan berat badan, pendidikan gizi, asupan zat gizi, IMT.

\section{PENDAHULUAN}

Kelebihan berat badan atau overweight dan obesitas yaitu keadaan tubuh yang abnormal karena

\footnotetext{
1. Rumah Sakit Khusus Prov Kalimantan Barat

2. Fakultas Kesehatan Masyarakat, Universitas Diponegoro

3. Fakultas Kedokteran, Universitas Diponegoro
}

timbunan lemak dalam tubuh yang berlebihan dan dapat mengganggu kesehatan ${ }^{1}$, disebut overweight bila Body Mass Index/ Indeks Massa Tubuh (BMI/ IMT) antara 25 - 29,9 dan obesitas bila $\geq 300^{2,3}$ Overweight dan obesitas merupakan suatu kondisi dengan penyebab multi faktor seperti gaya hidup yang dipengaruhi oleh lingkungan, perilaku, psikologis, fisiologis, sosial dan faktor genetik. ${ }^{4}$ Kelebihan berat 
badan pada remaja disebabkan oleh asupan energi yang melebihi kebutuhan atau pemakaian energi yang kurang dan berkaitan dengan riwayat kebiasaan makan dan frekuensi asupan makanan berkalori tinggi ${ }^{5}$ serta disebabkan masih rendahnya pengetahuan gizi remaja. ${ }^{6}$ Penelitian Barzegari dan kawan-kawan pada mahasiswa di Iran menunjukkan nilai pengetahuan gizi mahasiswa yang rendah yaitu $57,28 \%$ untuk mahasiswa laki-laki dan $56,71 \%$ untuk mahasiswa perempuan.

Overweight dan obesitas saat remaja merupakan faktor risiko penyebab penyakit kronis dan berhubungan dengan peningkatan risiko obesitas dimasa dewasa sebesar 50\%-80\%., ${ }^{7,8}$ Kelebihan berat badan dapat dicegah dengan mengubah pola hidup sehat seperti mengubah pola makan dan meningkatkan aktivitas fisik serta melakukan upaya peningkatan kesehatan di masyarakat seperti memberikan pendidikan kesehatan sebagai upaya tindakan preventif dan promotif. ${ }^{9}$ Pendidikan kesehatan merupakan salah satu bentuk intervensi kesehatan masyarakat yang dapat mempengaruhi perilaku hidup sehat, ${ }^{9,10}$ yang pelaksanaannya dapat dilakukan di sekolah. ${ }^{11}$

Pendidikan gizi menghasilkan peningkatan pengetahuan, kesadaran dan perubahan perilaku untuk mencapai keadaan gizi dan kesehatan yang optimal. ${ }^{12}$ Pendidikan gizi perlu ditingkatkan pada anak sekolah dan dalam pelaksanaannya perlu kerjasama dengan sektor pendidikan untuk merumuskan kurikulum gizi sesuai dengan tingkatan sekolah. ${ }^{13}$ Pendidikan gizi di sekolah dapat diberikan oleh guru yang telah mendapat pelatihan pendidikan gizi atau diberikan langsung petugas gizi. Materi pendidikan gizi dapat disusun dalam mata pelajaran muatan lokal atau pada mata pelajaran lain yang merupakan kegiatan ekstra kurikuler di sekolah. ${ }^{14}$

Penelitian Dali dan kawan-kawan tentang penerapan mulok ilmu gizi berbasis makanan khas daerah pada remaja SMU di Gorontalo menunjukkan nilai pengetahuan gizi tinggi setelah intervensi lebih besar pada kelompok perlakuan yaitu sebesar 52,9\% dibandingkan dengan kelompok kontrol yaitu hanya $23,1 \% .{ }^{15}$ Penelitian yang sama oleh Sungkowo dan kawan-kawan pada remaja menunjukkan perbedaan yang signifikan antara nilai rata-rata pengetahuan pangan dan gizi sebelum dan setelah intervensi pada kelompok perlakuan. Sebelum penelitian nilainya tergolong rendah $(51,92)$ dan setelah penelitian nilainya meningkat menjadi baik $(75,13) .{ }^{16}$ Penelitian yang dilakukan Podojoyo pada remaja SMA overweight dan obesitas di Palembang menunjukkan perbedaan pada konsumsi zat gizi dan berat badan sebelum dan setelah dilakukan konseling gizi. Sebelum penelitian rata-rata asupan zat gizi tinggi (melebihi kebutuhan tubuh) dan setelah penelitian asupan zat gizi rata-rata baik (sesuai kebutuhan tubuh) dan terjadi penurunan nilai IMT. ${ }^{17}$

Tujuan utama penanggulangan overweight dan obesitas pada anak dan remaja adalah mencapai berat badan normal dengan mempertimbangkan pertumbuhan dan perkembangan. Perubahan perilaku efektif dalam penanggulangan obesitas yang terdiri dari perubahan perilaku, modifikasi diet dan modifikasi kebiasaan aktifitas fisik. ${ }^{18}$ Rekomendasi mengurangi asupan kalori, lebih banyak konsumsi serat, membatasi gula dan lemak serta olahraga 30 menit perhari (jalan/ aerobik). ${ }^{19}$ Upaya yang dapat dilakukan adalah memberikan pendidikan gizi pada remaja SMA dengan kelebihan berat badan dengan harapan dapat memperbaiki keadaan gizi yang lebih baik dan pengetahuan yang diperoleh masih dapat diingat pada masa dewasa. Tujuan penelitian adalah menganalisis pengaruh intervensi pendidikan gizi terhadap peningkatan pengetahuan gizi, perubahan asupan zat gizi (Tingkat Kecukupan Energi, Tingkat Kecukupan Protein, persentase asupan karbohidrat, persentase asupan lemak dan asupan serat) dan Indeks Massa Tubuh remaja dengan kelebihan berat badan.

\section{BAHAN DAN METODE}

Penelitian quasi eksperimen with control group pre pos-test design yang dilaksanakan bulan MaretJuni 2014 di SMA Negeri 4 dan SMA Negeri 6 kota Pontianak. Subjek adalah siswa kelas sepuluh umur 14 - 18 tahun dengan $\quad$ IMT $\geq 25$ yang dipilih secara purposive sampling dan berjumlah 73 orang. Variabel independent adalah intervensi pendidikan gizi, variabel antara adalah pengetahuan gizi dan asupan zat gizi (Tingkat Kecukupan Energi, Tingkat Kecukupan Protein, persentase asupan karbohidrat, persentase asupan lemak dan asupan serat), variabel dependent adalah IMT dengan variabel pengganggu imformasi gizi dari media lain, ketersediaan makanan dalam keluarga dan lingkungan sekolah serta aktivitas fisik.

Pendidikan gizi adalah penyampaian pesan gizi melalui proses pembelajaran di kelas dengan metode ceramah, data pengetahuan gizi diperoleh dengan memberikan tes pengetahuan gizi, data asupan zat gizi terdiri dari Tingkat Kecukupan Energi (TKE), Tingkat Kecukupan Protein (TKP), persentase asupan karbohidrat, persentase asupan lemak dan asupan serat yang diperoleh dari recall konsumsi menggunakan FFQ semi kuantitatif. IMT dihitung berdasarkan nilai $z$-score untuk umur dan jenis kelamin subjek dengan menggunakan program WHO anthro-plus. Analisis data menggunakan analisis univariat, dan multivariat. Data diuji dengan Paired t-test, wilcoxon test, Independent t-test, Mann-Whitney Test dan uji multivariat kovariat. 


\section{HASIL}

\section{Karakteristik Subjek Penelitian}

Subjek yang diteliti sebanyak 73 remaja kelabihan berat badan, karakteristik subjek dapat dilihat pada Tabel 1. Sebagian besar jenis kelamin kedua kelompok adalah perempuan $(\geq 56)$, kelebihan berat badan/ obesitas subjek kedua kelompok dipengaruhi oleh faktor kegemukan kedua orang tua $(\geq$ $73 \%$ ) dan pekerjaan kepala rumah tangga kedua kelompok pegawai swasta (kelompok perlakuan44\%, kelompok kontrol 35\%).

Tabel 1. Karakteristik Subyek Penelitian Menurut Jenis Kelamin, Faktor Keturunan dalam Keluarga dan Pekerjaan Orangtua

\begin{tabular}{|c|c|c|c|c|}
\hline \multirow{2}{*}{ Karakteristik } & \multicolumn{2}{|c|}{ Kel.Perlakuan } & \multicolumn{2}{|c|}{ Kel.Kontrol } \\
\hline & $\mathbf{N}$ & $\%$ & $\mathbf{n}$ & $\%$ \\
\hline \multicolumn{5}{|l|}{ Jenis kelamin } \\
\hline - Laki-laki & 16 & 44 & 9 & 24 \\
\hline - Perempuan & 20 & 56 & 28 & 76 \\
\hline \multicolumn{5}{|l|}{ Faktor keturunan } \\
\hline - Ada & 29 & 81 & 27 & 73 \\
\hline - Tidak ada & 7 & 19 & 10 & 27 \\
\hline \multicolumn{5}{|l|}{ Pekerjaan orangtua } \\
\hline - PNS & 9 & 25 & 8 & 22 \\
\hline - ABRI/TNI/POLRI & 1 & 3 & 0 & 0 \\
\hline - Pegegawai swasta & 16 & 44 & 13 & 35 \\
\hline - Pedagang/wiraswasta & 1 & 3 & 2 & 5 \\
\hline - Buruh/tani/pekerja tidak & 3 & 8 & 7 & 19 \\
\hline tetap & 6 & 17 & 7 & 19 \\
\hline - Pensiunan & & & & \\
\hline $\mathbf{n}$ & 36 & 100 & 37 & 100 \\
\hline
\end{tabular}

Tabel 2. Karakteristik Subjek Penelitian Pada Kelompok Perlakuan dan Kelompok Kontrol di Awal Penelitian

\begin{tabular}{|c|c|c|c|c|c|c|c|}
\hline \multirow{2}{*}{$\begin{array}{c}\text { Karakteristik } \\
\text { Subjek }\end{array}$} & \multicolumn{3}{|c|}{$\begin{array}{c}\text { Kelompok Perlakuan } \\
(\mathrm{n}=36)\end{array}$} & \multicolumn{3}{|c|}{$\begin{array}{c}\begin{array}{c}\text { Kelompok Kontrol } \\
(n=37)\end{array} \\
\end{array}$} & \multirow[t]{2}{*}{$p$} \\
\hline & $\begin{array}{c}\text { Mini- } \\
\text { mal }\end{array}$ & $\begin{array}{l}\text { Mak- } \\
\text { simal }\end{array}$ & Rerata \pm SD & $\begin{array}{l}\text { Mini } \\
\text {-mal }\end{array}$ & $\begin{array}{l}\text { Mak- } \\
\text { simal }\end{array}$ & Rerata \pm SD & \\
\hline Umur (tahun) & 14 & 17 & $15 \pm 0,65$ & 14 & 17 & $15 \pm 0,65$ & $0,921^{\mathrm{b}}$ \\
\hline Pendidikan orang tua (tahun) & 6 & 19 & $12 \pm 4,37$ & 6 & 17 & $10 \pm 2,96$ & $0,935^{b}$ \\
\hline Pengetahuan gizi (skor) & 33 & 73 & $52,69 \pm 10,34$ & 27 & 80 & $53,84 \pm 11,23$ & $0,951^{\mathrm{a}}$ \\
\hline Tingkat Kecukupan Energi (\%) & 92 & 150 & $110 \pm 13$ & 86 & 140 & $106,03 \pm 12,7$ & $0,820^{\mathrm{a}}$ \\
\hline Tingkat Kecukupan Protein (\%) & 64 & 129 & $103 \pm 14,15$ & 80 & 127 & $98,43 \pm 12,01$ & $0,837^{\mathrm{a}}$ \\
\hline Persentase asupan karbohidrat (\%) & 52 & 81 & $66 \pm 6,42$ & 53 & 80 & $62,6 \pm 7,15$ & $0,835^{\mathrm{a}}$ \\
\hline Persentase asupan lemak (\%) & 20 & 37 & $27 \pm 4,36$ & 18 & 33 & $26,24 \pm 4,37$ & $0,984^{\mathrm{a}}$ \\
\hline Asupan serat (gr) & 3,3 & 15,5 & $8,43 \pm 2,99$ & 3,5 & 21,9 & $11,27 \pm 5,08$ & $0,864^{\mathrm{a}}$ \\
\hline $\operatorname{IMT}\left(\mathrm{kg} / \mathrm{m}^{2}\right)$ & 25 & 38 & $28 \pm 3,65$ & 25 & 42,5 & $27,33 \pm 3,73$ & $1,000^{\mathrm{b}}$ \\
\hline
\end{tabular}

andependent t-test ${ }^{b}$ Mann-Whitney $U$

Pada Tabel 2. diperoleh karakteristik subjek penelitian kelompok perlakuan dan kelompok kontrol di awal penelitian. Tidak terdapat perbedaan rerata umur subjek, pendidikan orang tua, pengetahuan gizi, Tingkat Kecukupan Energi, Tingkat Kecukupan
Protein, persentase asupan karbohidrat, persentase asupan lemak, asupan serat dan IMT. Hal ini menunjukkan bahwa penelitian ini dimulai dengan kondisi karakteristik subjek yang sama dari kedua kelompok. 
Tabel 3. Deskripsi Variabel Pengganggu

\begin{tabular}{lccccccc}
\hline & \multicolumn{9}{c}{ Kelompok Perlakuan (n=36) } & \multicolumn{3}{c}{ Kelompok Kontrol $(\mathbf{n}=37)$} & \\
\cline { 2 - 7 } Variabel Pengganggu & $\begin{array}{c}\text { Mini- } \\
\text { mal }\end{array}$ & $\begin{array}{c}\text { Mak- } \\
\text { simal }\end{array}$ & Rerata \pm SD & $\begin{array}{c}\text { Mini } \\
\text {-mal }\end{array}$ & $\begin{array}{c}\text { Mak- } \\
\text { simal }\end{array}$ & $\begin{array}{c}\text { Rerata } \pm \\
\text { SD }\end{array}$ & \\
\hline Informasi media lain (skor) & 50 & 100 & $95,14 \pm 11,68$ & 25 & 100 & $89,96 \pm 18,12$ & 0,173 \\
Persediaan makanan (skor) & 33 & 83 & $53,69 \pm 12,06$ & 17 & 100 & $52,78 \pm 18,64$ & 0,882 \\
Aktivitas fisik (skor PAL) & 1,13 & 1,47 & $1,29 \pm 0,08$ & 1,15 & 1,7 & $1,38 \pm 0,11$ & 0,001 \\
\hline
\end{tabular}

Uji Mann-Whitney U

Tabel 3. menunjukkan rerata skor informasi gizi dari media lain dan persediaan makanan dalam keluarga lebih tinggi pada kelompok perlakuan. Analisis statistik menunjukkan nilai $p>0,05$ ini berarti informasi gizi dari media lain yang dan persediaan makanan dalam keluarga diperoleh kedua kelompok adalah sama. Aktivitas fisik kelompok perlakuan lebih rendah dari kelompok kontrol, hasil analisis statistik menunjukkan terdapat perbedaan rerata aktivitas fisik antara kelompok perlakuan dan kontrol $(p<0,001)$. Ini berarti aktivitas fisik kedua kelompok setelah satu bulan perlakuan tidak sama, aktivitas kelompok kontrol lebih baik dari kelompok perlakuan.

Tabel 4. Perbedaan Pengetahuan Gizi, Asupan Zat Gizi dan IMT Siswa Kelebihan Berat Badan

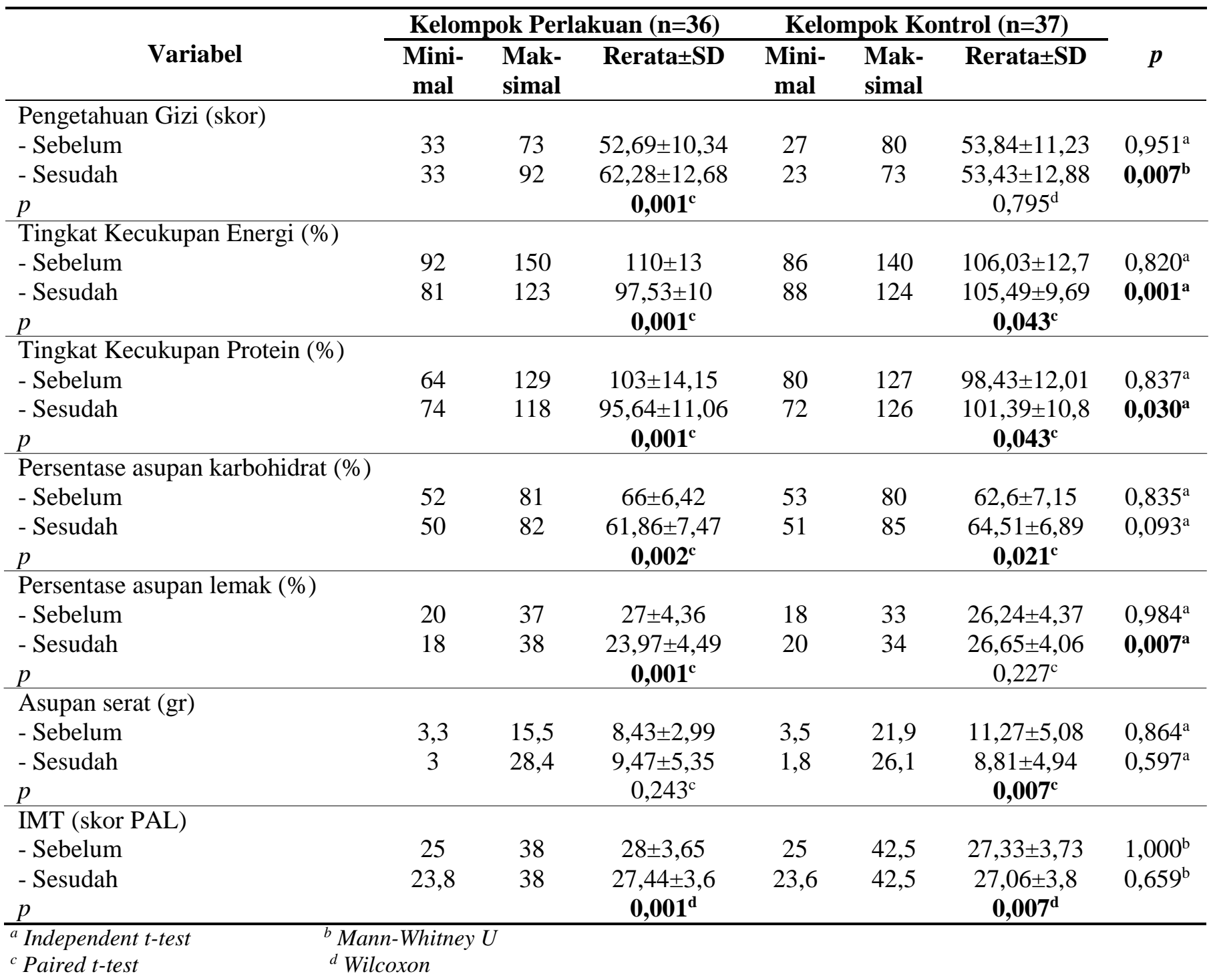




\section{Perbedaan Pengetahuan Gizi, Asupan Zat Gizi dan IMT Siswa Kelebihan Berat Badan Sebelum dan Sesudah Intervensi Pendidikan Gizi pada Kelompok Perlakuan dan Kelompok Kontrol}

Pendidikan gizi pada kelompok perlakuan diberikan seminggu sekali selama 3 bulan dengan memberikan modul dan pendidikan gizi pada kelompok kontrol diberikan hanya sekali selama 3 bulan penelitian tanpa pemberian modul. Perbedaan pengetahuan gizi, perubahan Tingkat Kecukupan Energi, Tingkat Kecukupan Protein, persentase asupan karbohidrat, persentase asupan lemak, asupan serat dan IMT remaja kelebihan berat badan pada kelompok perlakuan dan kontrol setelah intervensi pendidikan gizi dapat dilihat pada Tabel 4 .

\section{Pengetahuan Gizi Subjek}

Pada Tabel 4. pengetahuan gizi kedua kelompok di awal penelitian adalah sama, hasil uji statistik independent $t$-test diperoleh nilai $p=0,951$ dan sesudah pendidikan gizi terdapat perbedaan rerata pengetahuan gizi antara kelompok perlakuan dan kontrol $(p=$ $0,007)$. Pada kelompok perlakuan terdapat perbedaan pengetahuan gizi sebelum dan setelah pendidikan gizi sedangkan pada kelompok kontrol tidak terdapat perbedaan.

\section{Asupan Zat Gizi Subjek}

Sebagian besar rerata asupan zat gizi kelompok perlakuan lebih besar dibandingkan dengan kelompok kontrol di awal penelitian. Hasil uji statistik menunjukkan nilai $p>0,05$, ini berarti tidak terdapat perbedaan rerata asupan zat gizi antara kelompok perlakuan dengan kelompok kontrol di awal penelitian dan asupan zat gizi kedua kelompok sebelum penelitian adalah sama.

1. Tingkat Kecukupan Energi

Terdapat perbedaan rerata Tingkat Kecukupan Energi yang bermakna sebelum dan sesudah intervensi pada kelompok perlakuan dan kelompok kontrol $(p<0,05)$. Sesudah pendidikan gizi terdapat perbedaan antara kelompok perlakuan dan kontrol, hasil analisis statistik diperoleh nilai $\quad p=0,001$.

2. Tingkat Kecukupan Protein

Terdapat perbedaan rerata Tingkat Kecukupan Protein yang bermakna sebelum dan sesudah intervensi pada kelompok perlakuan dan kelompok kontrol $(p<0,05)$. Sesudah pendidikan gizi terdapat perbedaan antara kelompok perlakuan dan kontrol, hasil analisis statistik diperoleh nilai $\quad p=0,030$.

3. Persentase Asupan Karbohidrat

Terdapat perbedaan rerata persentase asupan karbohidrat yang bermakna sebelum dan sesudah perlakuan pada kelompok perlakuan dan kontrol.
Hasil ini diperkuat dengan uji statistik yang menunjukkan sigfikansi $<0,05$ pada kedua kelompok. Sesudah pendidikan gizi tidak terdapat perbedaan antara kelompok perlakuan dan kontrol, hasil analisis statistik diperoleh nilai $p=0,093$.

4. Persentase Asupan Lemak

Pada kelompok perlakuan terdapat perbedaan persentase asupan lemak sebelum dan setelah pendidikan gizi sedangkan pada kelompok kontrol tidak terdapat perbedaan. Sesudah pendidikan gizi terdapat perbedaan antara kelompok perlakuan dan kontrol, hasil analisis statistik diperoleh nilai $p=0,007$.

5. Asupan Serat

Pada kelompok perlakuan terdapat perubahan asupan serat yang meningkat tetapi hasil iji statistik diperoleh nilai $p>0,05$ ini berarti tidak terdapat perbedaan asupan serat sebelum dan setelah pendidikan gizi sedangkan pada kelompok kontrol terdapat perbedaan. Sesudah pendidikan gizi tidak terdapat perbedaan antara kelompok perlakuan dan kontrol, hasil analisis statistik diperoleh nilai $p=0,597$.

\section{Indeks Massa Tubuh Subjek}

Terdapat perbedaan rerata IMT yang bermakna sebelum dan sesudah pendidikan gizi pada kelompok perlakuan dan kontrol. Hasil ini diperkuat dengan uji statistik yang menunjukkan sigfikansi $<0,05$ pada kedua kelompok. Sesudah pendidikan gizi tidak terdapat perbedaan IMT antara kelompok perlakuan dan kontrol, hasil analisis statistik diperoleh nilai $p=$ 0,659 .

\section{Perbedaan Peningkatan Pengetahuan Gizi, Perubahan Asupan Zat Gizi dan IMT Antara Kelompok Perlakuan dan Kontrol Sesudah Pendidikan Gizi}

Pendidikan gizi selama 3 bulan menghasilkan perubahan pada variabel penelitian kelompok perlakuan dan kontrol. Pada Tabel 5. dapat dilihat perubahan nilai atau delta $(\Delta)$ pada variabel pengetahuan gizi, Tingkat Kecukupan Energi, Tingkat Kecukupan Protein, persentase asupan karbohidrat, persentase asupan lemak, asupan serat dan IMT siswa kelompok perlakuan dan kontrol. Perubahan nilai yang terjadi pada kedua kelompok berupa perubahan yang nilainya positif dan negatif.

Pada Tabel 5. menunjukkan rerata perubahan pengetahuan gizi, Tingkat Kecukupan Energi, Tingkat Kecukupan Protein, persentase asupan karbohidrat, persentase asupan lemak, asupan serat dan IMT siswa. Hasil uji statistik menunjukkan nilai yang signifikan pada semua variabel dengan nilai $p<0,05$ yang berarti terdapat perbedaan rerata perubahan pengetahuan gizi, 
perubahan Tingkat Kecukupan Energi, perubahan Tingkap Kecukupan Protein, perubahan persentase asupan karbohidrat, perubahan persentase asupan lemak, perubahan asupan serat dan perubahan IMT yang bermakna antara kelompok perlakuan dan kelompok kontrol, perubahan pada kelompok perlakuan lebih tinggi daripada kelompok kontrol.

Tabel 5. Perubahan Skor Variabel Penelitian Sesudah Pemberian Intervensi Pendidikan Gizi

\begin{tabular}{|c|c|c|c|c|c|c|c|}
\hline \multirow[t]{2}{*}{ Variabel } & \multicolumn{3}{|c|}{$\begin{array}{c}\text { Kelompok Perlakuan } \\
n=36\end{array}$} & \multicolumn{3}{|c|}{$\begin{array}{l}\text { Kelompok Kontrol } \\
\mathbf{n}=37\end{array}$} & \multirow[t]{2}{*}{$p$} \\
\hline & $\begin{array}{c}\text { Min- } \\
\text { mal }\end{array}$ & $\begin{array}{l}\text { Mak- } \\
\text { simal }\end{array}$ & Rerata \pm SD & $\begin{array}{l}\text { Mini } \\
\text {-mal }\end{array}$ & $\begin{array}{l}\text { Mak- } \\
\text { simal }\end{array}$ & Rerata \pm SD & \\
\hline$\Delta$ Pengetahuan gizi (skor) & -15 & 38 & $9,58 \pm 11,82$ & -19 & 20 & $-0,41 \pm 10,04$ & $\mathbf{0 , 0 0 1 ^ { \mathrm { a } }}$ \\
\hline$\Delta$ Tingkat Kecukupan Energi (\%) & -50 & 18 & $-12,42 \pm 16,77$ & -24 & 14 & $-0,54 \pm 10,18$ & $0,001^{b}$ \\
\hline$\Delta$ Tingkat Kecukupan Protein $(\%)$ & -28 & 32 & $-7,61 \pm 12,05$ & -14 & 24 & $2,91 \pm 8,52$ & $0,001^{\mathrm{a}}$ \\
\hline$\Delta$ persentase asupan karbohidrat (\%) & -17 & 9 & $-3,78 \pm 6,71$ & -8 & 13 & $1,89 \pm 4,78$ & $0,001^{\mathrm{a}}$ \\
\hline$\Delta$ Persentase asupan lemak (\%) & -17 & 5 & $-3,11 \pm 3,96$ & -4 & 6 & $0,38 \pm 2,02$ & $\mathbf{0 , 0 0 1 ^ { b }}$ \\
\hline$\Delta$ Asupan serat (gr) & $-9,4$ & 17,6 & $1,05 \pm 5,29$ & $-15,2$ & 8,6 & $-2,74 \pm 5,04$ & $\mathbf{0 , 0 0 3} 3^{\mathrm{a}}$ \\
\hline$\Delta \mathrm{IMT}\left(\mathrm{kg} / \mathrm{m}^{2}\right)$ & $-3,0$ & 0,4 & $-0,58 \pm 0,67$ & $-0,9$ & 0,3 & $-0,12 \pm 0,34$ & $\mathbf{0 , 0 0 1} 1^{b}$ \\
\hline
\end{tabular}

Informasi Gizi Dari Media Lain, Persediaan Makanan Dalam Keluarga/ Lingkungan Sekolah dan Aktivitas fisik

Informasi gizi dari media lain, persediaan makanan dalam keluarga/ lingkungan sekolah dan aktivitas fisik merupakan variabel pengganggu atau perancu yang dapat memberi pengaruh terhadap hasil penelitian. Data diperoleh setelah satu bulan kegiatan pendidikan gizi dilakukan. Rerata informasi gizi dari media lain kelompok perlakuan lebih tinggi dari pada kelompok kontrol yaitu 95,14 $\pm 11,68$ dan 89,96 $\pm 18,12$. Hasil uji statistik $p=0,173$, ini menunjukkan tidak terdapat perbedaan rerata informasi gizi dari media lain pada kedua kelompok. Rerata persediaan makanan dalam keluarga/ lingkungan sekolah kelompok perlakuan lebih tinggi dari pada kelompok kontrol yaitu $53,69 \pm 12,06$ dan $52,78 \pm 18,64$. Hasil uji statistik $p=0,882$, ini menunjukkan tidak terdapat perbedaan rerata persediaan makanan dalam keluarga pada kedua kelompok. Rerata aktivitas fisik kelompok perlakuan lebih rendah dari pada kelompok kontrol yaitu $1,29 \pm 0,08$ dan $1,38 \pm 0,11$. Hasil uji statistik $p=0,001$, ini menunjukkan terdapat perbedaan rerata aktivitas fisik pada kedua kelompok.

\section{PEMBAHASAN}

\section{Pengetahuan Gizi}

Sesudah intervensi pendidikan gizi terdapat perbedaan rerata pengetahuan gizi yang bermakna sebelum dan sesudah intervensi pendidikan gizi selama 3 bulan pada kelompok perlakuan, sedangkan kelompok kontrol tidak terdapat perbedaan rerata. Sesudah perlakuan rerata skor pengetahuan gizi kelompok perlakuan meningkat sedangkan kelompok kontrol menurun. Hal ini sejalan dengan penelitian Rostania tentang pengaruh edukasi gizi terhadap perubahan pengetahuan dan gaya hidup sedentary pada anak gizi lebih di SDN yang menunjukkan perbedaan signifikan sebelum dan setelah menerima edukasi gizi $(p=0,001) .{ }^{20}$

Pendidikan gizi yang dilakukan secara kontinyu dengan metode pembelajaran di kelas dan materi yang disampaikan disusun dalam buku modul yang dibagikan ke siswa dapat meningkatkan pengetahuan gizi subjek. Hal ini didukung oleh penelitian Dali yang menunjukkan hubungan yang bermakna antara materi ilmu gizi dengan pengetahuan dan sikap siswa SMA yang menerapkan mulok ilmu gizi $(p<0,05) \cdot{ }^{21}$ Sebelum intervensi pendidikan gizi, pengetahuan gizi kedua kelompok adalah sama dan sesudah pendidikan gizi terdapat perbedaan pengetahuan gizi antara kelompok perlakuan dan kontrol $(p<0,05)$. Pengetahuan gizi kelompok perlakuan meningkat sedangkan kelompok kontrol menurun.

\section{Asupan Zat Gizi}

\section{Tingkat Konsumsi Energi (TKE)}

Sesudah intervensi pendidikan gizi terdapat perbedaan rerata TKE pada kelompok perlakuan 
dan kontrol $(p<0,05)$. Hasil penelitian ini sama dengan penelitian Prabowo tentang pengaruh pendidikan gizi yang menunjukkan terdapat perbedaan rerata asupan energi sesudah mendapatkan pendidikan gizi $(p=0,001)$. Pendidikan gizi merupakan suatu upaya mendidik remaja untuk merubah perilaku konsumsi sesuai kaidah-kaidah gizi ${ }^{22}$ yang pelaksanaannya sudah direncanakan dengan tujuan untuk mempengaruhi perilaku sehingga remaja melakukan pesan/informasi yang diberikan dalam proses pendidikan. ${ }^{23}$

Sebelum intervensi pendidikan gizi TKE kedua kelompok adalah sama dan setelah pendidikan gizi terdapat perbedaan rerata antara kelompok perlakuan dan kontrol. Terdapat penurunan TKE kedua kelompok tetapi penurunan kelompok perlakuan lebih besar daripada kelompok kontrol, TKE kelompok perlakuan berkurang sebesar $12,47 \%$ sedangkan kelompok kontrol $0,54 \%$.

\section{Tingkat Konsumsi Protein (TKP)}

Terdapat perbedaan rerata Tingkat Kecukupan Protein yang bermakna sebelum dan sesudah 3 bulan intervensi pendidikan gizi pada kelompok perlakuan dan kelompok kontrol. Sesudah intervensi pendidikan gizi asupan protein kelompok perlakuan menurun sedangkan kelompok kontrol meningkat, intervensi pendidikan gizi dapat merubah asupan protein kelompok perlakuan menjadi lebih baik. Sesudah menerima pendidikan gizi Tingkat Kecukupan Protein kelompok perlakuan berkurang 7,6\%. Hasil ini sama dengan penelitian Prabowo tentang pengaruh pendidikan gizi melalui media komik yang menunjukkan nilai yang signifikan pada asupan protein sebelum dan sesudah 2 bulan menerima pendidikan gizi $(p=$ $0,001)$, sesudah mendapat pendidikan gizi asupan protein menurun $7,17 \% .^{24}$

Sebelum perlakuan diberikan TKP kedua kelompok sama, hasil uji statistik menunjukkan signifikansi sebesar 0,837 dan sesudah perlakuan terdapat perbedaan rerata TKP yang bermakna antara kelompok perlakuan dan kelompok kontrol $(p=0,03)$. Intervensi pendidikan gizi yang diberikan pada kedua kelompok berdampak pada perilaku dalam pemilihan makanan. Hasil penelitian ini sejalan dengan penelitian Dali yang menunjukkan bahwa penerapan ilmu gizi memberikan pengaruh terhadap tindakan dalam memilih makanan $(p=0,044) .{ }^{21}$ Penelitian Thasim tentang pengaruh edukasi gizi pada anak gizi lebih juga menunjukkan perbedaan rerata asupan protein sebelum dan setelah mendapatkan edukasi gizi $(p=$ $0,018) .{ }^{25}$

\section{Persentase Asupan Karbohidrat}

Terdapat perbedaan rerata persentase asupan karbohidrat yang bermakna sebelum dan sesudah perlakuan pada kelompok perlakuan dan kontrol. Hasil ini diperkuat dengan uji statistik, diperoleh nilai $p<0,05$ pada kedua kelompok. Setelah intervensi pendidikan gizi persentase asupan karbohidrat kelompok perlakuan menurun sedangkan kelompok kontrol malah meningkat. Intervensi pendidikan gizi pada kelompok perlakuan dapat merubah asupan karbohidrat menjadi lebih baik yaitu dari $66 \%$ menjadi $61,86 \%$. Pendidikan gizi merupakan suatu upaya mendidik remaja untuk merubah perilaku konsumsi sesuai kaidah-kaidah gizi. ${ }^{22}$

Sebelum perlakuan, persentase asupan karbohidrat kedua kelompok sama dan sesudah perlakuan selama 3 bulan persentase asupan karbohidrat tidak menunjukkan perbedaan rerata yang signifikan antara kelompok perlakuan dan kelompok kontrol $(p=0,093)$. Hasil penelitian ini sejalan dengan penelitian Schmidt pada remaja putri SMA di Michigan yang menunjukkan tidak terdapat perbedaan asupan karbohidrat antara kelompok perlakuan dan kontrol setelah mendapatkan pendidikan gizi $(p>0,05) .{ }^{26}$

Hasil recall konsumsi pada kelompok perlakuan setiap bulan dengan metode FFQ semi kuantitatif menunjukkan perubahan asupan karbohidrat menurun menjadi lebih baik. Subjek melakukan pembatasan dalam konsumsi minuman siap saji dan makanan jajanan seperti teh es manis dan gorengan.

\section{Persentase Asupan Lemak}

Terdapat perbedaan rerata persentase asupan lemak yang bermakna sebelum dan sesudah intervensi pendidikan gizi pada kelompok perlakuan sedangkan kelompok kontrol tidak. Sesudah pendidikan gizi persentase asupan lemak kelompok perlakuan menurun atau berkurang dan kelompok kontrol meningkat. Sebelum perlakuan diberikan persentase asupan lemak kedua kelompok $\operatorname{sama}(p=0,984$ dan sesudah perlakuan terdapat perbedaan rerata persentase asupan lemak yang bermakna antara kelompok perlakuan dan kontrol, hasil uji statistik menunjukkan perbedaan yang signifikan $\quad(p=0,007)$.

Pendidikan gizi yang dilakukan secara kontinyu dapat merubah asupan lemak subjek pada kelompok perlakuan. Hal ini sejalan dengan penelitian Thasim tentang pengaruh edukasi gizi terhadap perubahan pengetahuan dan asupan zat gizi pada anak gizi lebih yang menunjukkan perbedaan signifikan rerata asupan lemak sebelum dan setelah menerima edukasi gizi $(p=0,002) \cdot{ }^{25}$ 
Hasil recall konsumsi kelompok perlakuan tiap bulan selama perlakuan terlihat jumlah asupan yang semakin baik, tiap bulannya persentase asupan lemak menurun dan diakhir perlakuan asupan lemak subjek sesuai dengan kebutuhan individu yaitu 23,97\% (asupan lemak anjuran 25\%). Hasil recall menunjukkan subjek membatasi konsumsi makanan yang kandungan lemaknya tinggi seperti sosis goreng, fast food dan makanan gorengan lainnya.

\section{Asupan Serat}

Persentase asupan serat sebelum dan sesudah intervensi pendidikan gizi 3 bulan pada kelompok perlakuan mengalami peningkatan sebesar 1,04 gr tetapi uji statistik diperoleh nilai $p=0,243 \mathrm{ini}$ berarti tidak terdapat perbedaan yang bermakna sebelum dan sesudah pendidikan gizi. Peningkatan asupan serat kelompok perlakuan sangat kecil sehingga bila dilakukan uji statistik hasilnya menjadi tidak bermakna. Hasil ini sejalan dengan penelitian Thasim dan kawan-kawan yang juga menunjukkan hasil yang tidak signifikan sebelum dan sesudah pendidikan gizi diberikan meskipun terjadi perubahan asupan serat yang lebih baik setelah perlakuan. ${ }^{25}$

Pada kelompok kontrol sebelum dan sesudah intervensi pendidikan gizi mengalami penurunan $2,41 \mathrm{gr}$, hasil uji statistik diperoleh nilai $p=0,007$ yang berarti terdapat perbedaan rerata asupan serat yang bermakna sebelum dan sesudah perlakuan pada kelompok kontrol, sesudah pendidikan gizi asupan serat kelompok kontrol mengalami penurunan.

\section{Indeks Massa Tubuh}

Terdapat penurunan rerata IMT yang bermakna sebelum dan sesudah pendidikan gizi pada kelompok perlakuan dan kelompok kontrol. Hasil uji statistik menunjukkan nilai yang signifikan pada kedua kelompok (kelompok perlakuan $p=0,001$ dan kelompok kontrol $p=0,007)$. Walaupun terjadi perubahan yang signifikan pada kelompok kontrol tetapi perubahan yang terjadi nilainya lebih kecil dari kelompok perlakuan. Hal ini sejalan dengan penelitian Widhayati yang menunjukkan bawa pendidikan gizi memberikan pengaruh yang baik terhadap penurunan persentil IMT pada remaja kelebihan berat badan dengan metode penyuluhan kelompok dan penyuluhan individu $(p=0,010$ dan $p=0,009)$. Terlihat bahwa nilai $p$ penyuluhan kelompok lebih kecil dibandingkan dengan kelompok individu. ${ }^{27}$

Sebelum perlakuan IMT kedua kelompok cenderung sama $(p=1,000)$ dan sesudah perlakuan selama 3 bulan hasilnya juga menunjukkan tidak terdapat perbedaan rerata IMT yang bermakna $(p=$ $0,659)$. Hasil penelitian ini sama dengan hasil penelitian Widhayati yang menunjukkan tidak ada perbedaan penurunan persentil IMT yang bermakna antara grup penyuluhan individu dengan grup penyuluhan kelompok sesudah pendidikan gizi diberikan $(p=0,786) .{ }^{27}$ Intervensi pendidikan gizi dapat memberikan perubahan IMT pada kedua kelompok tetapi perubahan yang terjadi secara statistik tidak signifikan.

Data aktivitas fisik sebagian besar subjek kelompok perlakuan dan kontrol termasuk sangat ringan (rerata $1,29 \pm 0,08$ kelompok perlakuan dan $1,38 \pm 0,11$ kelompok kontrol) tetapi skornya lebih tinggi pada kelompok kontrol. Aktivitas fisik kelompok kontrol lebih tinggi dari kelompok perlakuan berdampak pada penurunan IMT kelompok kontrol sebagai akibat penggunaan energi untuk aktivitas fisik kelompok kontrol lebih banyak dan ini mempengaruhi penurunan berat badan kelompok kontrol.

\section{Perbedaan Perubahan Pengetahuan Gizi, Asupan Zat Gizi dan IMT Antara Kelompok Perlakuan dan Kontrol}

Pendidikan gizi selama 3 bulan menghasilkan perubahan pada variabel penelitian kelompok perlakuan dan kontrol. Pada Tabel 4. dapat dilihat perubahan nilai atau delta $(\Delta)$ pada variabel pengetahuan gizi, Tingkat Kecukupan Energi, Tingkat Kecukupan Protein, persentase asupan karbohidrat, persentase asupan lemak, asupan serat dan IMT siswa kelompok perlakuan dan kontrol sesudah intervensi pendidikan gizi. Hasil uji statistik menunjukkan nilai yang signifikan pada semua variabel dengan nilai $p<$ 0,05 .

Rerata perubahan pengetahuan gizi kelompok perlakuan meningkat sebesar $9,58 \pm 11,82$ sedangkan kelompok kontrol menurun $0,40 \pm 10,04$. Rerata asupan zat gizi pada kelompok perlakuan berkurang (kecuali asupan serat meningkat $1,05 \pm 5,29$ gr) sedangkan kelompok kontrol meningkat (meskipun ada asupan zat gizi yang berkurang tapi skornya lebih kecil dibandingkan dengan kelompok perlakuan). Rerata IMT kedua kelompok berkurang, kelompok perlakuan berkurang $0,58 \pm 0,7 \mathrm{~kg} / \mathrm{m}^{2}$ sedangkan kelompok kontrol berkurang $0,12 \pm 0,34 \mathrm{~kg} / \mathrm{m}^{2}$.

Intervensi pendidikan gizi yang diberikan pada kedua kelompok berdampak pada perilaku dalam pemilihan makanan. Hasil penelitian ini sejalan dengan penelitian Dali yang menunjukkan bahwa penerapan ilmu gizi memberikan pengaruh terhadap tindakan dalam memilih makanan $(p=0,044) .{ }^{21}$ Pada kelompok perlakuan peningkatan pengetahuan yang dimiliki siswa dapat merubah pola konsumsi makanan menjadi lebih baik yang sesuai dengan anjuran kesehatan. Perilaku gizi yang kurang tepat dapat diubah melalui pendidikan gizi dan upaya-upaya pendidikan gizi pada remaja lebih efektif dilakukan di sekolah. ${ }^{28}$ 
Pengetahuan yang telah diperoleh siswa selama penelitian pada kelompok perlakuan melekat dalam ingatan subyek dan berpotensi untuk berperilaku kesehatan yang lebih baik dan ini sejalan dengan konsep perilaku menurut Green yang menyatakan perubahan perilaku kesehatan dipengaruhi oleh faktor pengetahuan dan sikap terhadap kesehatan. ${ }^{29}$ Pengetahuan gizi yang dimiliki seseorang dapat mempengaruhi dalam memilih makanan. ${ }^{30}$

\section{Pengaruh Intervensi Pendidikan Gizi Terhadap Peningkatan Pengetahuan Gizi, Perubahan Asupan Zat Gizi dan IMT Siswa Setelah Dikontrol dengan Pengaruh Informasi Media Lain, Ketersediaan Makanan Dalam Keluarga dan Lingkungan Sekolah serta Aktivitas Fisik}

Dalam penelitian ini pengaruh intervensi pendidikan gizi terhadap peningkatan pengetahuan gizi, perubahan asupan zat gizi dan IMT kemungkinan dipengaruhi oleh faktor luar yang tidak ikut diteliti. Faktor yang diperkirakan dapat berpengaruh terhadap hasil penelitian diantaranya faktor informasi media lain, faktor ketersediaan makanan dalam keluarga dan lingkungan sekolah serta faktor aktivitas fisik individu yang selanjutnya disebut sebagai variabel pengganggu. Informasi gizi dari media lain dapat berkontribusi terhadap peningkatan pengetahuan gizi, ketersediaan makanan dalam keluarga dan lingkungan sekolah berpengaruh terhadap asupan zat gizi dan aktivitas fisik berpengaruh pada IMT.

Untuk melihat pengaruh variabel pengganggu terhadap perubahan pengetahuan gizi, asupan zat gizi dan IMT dilakukan analisis multivariat yaitu analisis kovarian. Hasil akhir kovarian diperoleh nilai $p>0,05$ sehingga informasi gizi dari media lain, ketersediaan makanan dalam keluarga/ lingkungan sekolah dan aktivitas fisik bukan merupakan variabel pengganggu dalam penelitian ini.

Pendidikan gizi diharapkan menjadi salah satu solusi untuk meningkatkan status gizi dan derajat kesehatan remaja ${ }^{28}$ dengan cara menyampaikan teori dan informasi tentang gizi pada sasaran pendidikan seperti remaja dengan metode belajar mengajar. Pendidikan gizi bertujuan meningkatkan pengetahuan gizi remaja, mengubah sikap serta mengarahkan perilaku ke arah yang lebih baik. ${ }^{21}$ Dalam penelitian ini pendidikan gizi merupakan salah satu pendidikan kesehatan yang sangat penting untuk merubah perilaku yang tidak sesuai dengan kaidah gizi. Intervensi pendidikan gizi pada remaja kelebihan berat badan dapat meningkatkan pengetahuan gizi dan kemudian pengetahuan gizi yang dimiliki dapat berpengaruh terhadap perilaku dalam memilih dan mengkonsumsi makanan yang memenuhi syarat kebutuhan zat gizi individu. Pengetahuan gizi yang dimiliki remaja kelebihan berat badan dapat menurunkan Tingkat
Kecukupan Energi, Tingkat Kecukupan Protein, persentase asupan karbohidrat, persentase asupan lemak dan meningkatkan asupan serat. Konsumsi zat gizi yang sesuai dengan kebutuhan remaja kelebihan berat badan akan berdampak pada penurunan IMT remaja kelebihan berat badan sehingga remaja memiliki kondisi gizi/status gizi yang lebih baik.

\section{SIMPULAN}

Pendidikan gizi pada remaja kelebihan berat badan menurunkan IMT remaja melalui peningkatan pengetahuan tentang gizi. Pengetahuan gizi remaja kelebihan berat badan dapat menurunkan Tingkat Kecukupan Energi, Tingkat Kecukupan Protein, persentase asupan karbohidrat, persentase asupan lemak dan meningkatkan asupan serat.

\section{DAFTAR PUSTAKA}

1. WHO, Obesity and Overweight. Factsheet $\mathrm{N}^{\circ} 311$ update March $2013 . \quad$ diunduh tanggal 5 November 2013 dari http: //www.who.int/ mediacentre/ factsheets/fs $311 /$ en/index.html.

2. Centre for Desease Control and Prevention, Defining Overweight and Obesity. diunduh tanggal 13 nop 13, dari http:// www.cdc.gov.

3. Huttunen, R., Syrjanen, J. 2012. Obesity and the risk and outcome of infection. International Journal of Obesity (2013) 37, 333-340; doi:10.1038/ijo. 2012.62, published online 1 May 2012 diunduh tanggal 26 Nopember 2013

4. Garko, M.G. 2011. Overweight and Obesity Epidemic in America - Part V: NonModifiableRisk Factors, Health and Wellbeing Monthly. www.letstalknutrition.com.

5. Suandi, I Kompiang Gede. 2004. Gizi Pada Masa Remaja dalam: Soetjiningsih Tumbuh Kembang Remaja dan Permasalahannya, Sagung Seto. Jakarta.

6. Barzegari, Ali., Mohsen., Ebrahimi., Aziz, Mohammad., Ranjbar, Kazem 2011, A Study of Nutrition Knowledge, Attitudes and Food Habits of College Students. World Applied Sciences Journal 15 (7): 1012-1017, 2011 ISSN 18184952@ IDOSI Publications, 2011.

7. Atmarita. 2005. Nutrition Problems in Indonesia, The article for An Integrated International Seminar and Workshop on Lifestyle - Related Diseases Gajah Mada University, 19-20 March. 2005.

8. Faghih Sh.,Taleban F., Abadi A., Ansari N 2009, Trends of overweight and obesity among 14-18 years old urban adolescent girls among senior high schools, Ahvaz, Iran. Iranian Journal of 
Diabetes and Lipid Disorders; 2009 pp 19-26, diunduh tanggal 15 November 2013

9. Notoatmodjo, Soekidjo 2007, Promosi Kesehatan dan Ilmu Perilaku, Rineka Cipta, Jakarta.

10. Hadisaputro, Soeharyo., Nizar, Muhammad., Suwandono, Agus 2011, Epidemiologi Manajerial Teori dan Aplikasi, Badan Penerbit Universitas Diponegoro, Semarang.

11. Fitriani, Sinta 2011, Promosi Kesehatan, Graha Ilmu, Yogyakarta.

12. Prosiding Widyakarya Nasional Pangan dan Gizi IX 26-27 Agustus 2008, Jakarta

13. Riskesdas 2010, Badan Penelitian dan Pengembangan Kesehatan Kemenkes, Jakarta

14. Departemen Pendidikan Nasional Tahun 2008, Model Mata Pelajaran Muatan lokal. http: Akhmadsudrajat.files.wordpress.com/2008/03/m odel-pengembangan-muatan-lokal.pdf diunduh tanggal 18 September 2013; 22.18 WIB

15. Dali, Nurdin A., Baha, Burhanuddin., Najamuddin, Ulfah., 2013, Pengaruh Penerapan Muatan Lokal Ilmu Gizi Berbasis Makanan Khas Daerah Gorontalo Terhadap Perilaku Gizi Siswa SMU Di Kota Gorontalo, Diunduh tanggal 10 November 2013, 15.29 WIBA

16. Sungkowo., Setiawan, Budi., Madanijah, Siti 2008, Intervensi Pengayaan Pengetahuan Pangan Dan Gizi Pada Muatan Lokal Untuk Sekolah Menengah Pertama Di Kabupaten Lampung Barat, Jurnal Gizi dan Pangan, November 2008 3(3): $156-166$

17. Podojoyo, Susyani, Nuryanto 2012, Konseling Gizi Terhadap Penurunan Berat Badan Remaja Overweight dan Obes di Kota Palembang, Jurnal Pembangunan Manusia, http://himcyoo.files.wordpres.com/2012/04

18. Williamson, Donald A., Martin, Corby K., Stewart, Tiffany M., Behavioral Strategies for Controlling Obesity dalam: Bray, George A., Ryan, Donna H. 2006, Overweight and the Metabolic Syndrome, Spcience + Business Media, LLC

19. Hendriyani, Heni 2010, Obesity and Social Appetite in Community, Artikel Gizi Indon 2010, 33(1):1-7

20. Rostania, Marisa., Syam, Aminuddin., Najamuddin, Ulfah. Pengaruh Edukasi Gizi Terhadap Perubahan Pengetahuan Dan Gaya Hidup Sedentary Pada Anak Gizi Lebih Di SDN Sudirman 1 Makassar Tahun 2013.

21. Dali, Nurdin A., Baha, Burhanuddin., Najamuddin, Ulfah. Pengaruh Penerapan Muatan Lokal Ilmu Gizi Berbasis Makanan Khas Daerah Gorontalo Terhadap Perilaku Gizi Siswa SMU Di Kota Gorontalo. 2013.
22. Suandi, IKG. Obesitas Pada Remaja dalam: Soetjiningsih Tumbuh Kembang Remaja dan Permasalahannya. Jakarta: Sagung Seto: 2004.

23. Fitriani, Sinta. Promosi Kesehatan. Yogyakarta: Graha Ilmu: 2011.

24. Prabowo, S.E. Djoeli Seto. Pengaruh Pendidikan Gizi melalui Media Komik Terhadap Pengetahuan dan Asupan Energi Protein pada Anak Sekolah Dasar Dengan Kelebihan Berat Badan. Tesis Ilmu Kedokteran. Semarang: Universitas Diponegoro: 2011.

25. Thasim, Sukmawati., Syam, Aminuddin., Najamuddin, Ulfah. Pengaruh Edukasi Gizi Terhadap Perubahan Pengetahuan dan Asupan Zat Gizi pada Anak Gizi Lebih di SDN Sudirman I Makassar tahun 2013. Artikel: FKM-Unhas Makassar.2013.

26. Rimbawan., Siagian, Albiner. Indeks Glikemik pangan. Jakarta: Penebar Swadaya: 2004.

27. Widhayati, Retno Endah. Efek Pendidikan Gizi Terhadap Perubahan Konsumsi Energi dan Indeks Masa Tubuh pada Remaja Kelebihan Berat Badan, Tesis Ilmu Kedokteran. Semarang: Universitas Diponegoro: 2009.

28. Centre for Desease Control and Prevention. Overweight and Obesity, Defining Overweight and Obesity. http://www,cdc.gov.obesity/adult/...

29. Notoatmodjo, Soekidjo. Promosi Kesehatan Teori dan Aplikasi. Jakarta: Rineka Cipta: 2010.

30. Proverawati, Atikah., Wati, Erna Kusuma.. Ilmu Gizi untuk Keperawatan dan Gizi Kesehatan. Yogyakarta: Nuha Medika: 2011. 